\title{
DEL AMOR Y LA MELANCOLÍA EN LA ESCRITURA DE TERESA DE LA PARRA
}

POR

\author{
DOUglas BoHORQueZ
}

Después de la lectura de sus textos de ficción, de sus cartas y de la contemplación de sus fotografías no puede uno sino asociar la imagen de Teresa de la Parra a la melancolía, a los viajes reales e imaginarios y quizá también a los amores imposibles. Viajes interiores, itinerario espiritual y vital de una mujer cuyo imaginario se torna cada vez más complejo, plural, difícil de descifrar. Más allá de las fechas, de la cronología, de los datos que nos aporta la crítica para estructurar u organizar su trayectoria intelectual, permanece la imagen no del todo revelada de una mujer enigmática, bella, exquisita, un poco ausente del paisaje físico, como en una constante huida y regreso de sí misma.

La escritura y la imagen vital de Teresa de la Parra se articulan en este diálogo textual del amor y la melancolía no para definirla sino para tejer un otro texto, denso, a su alrededor, tan seductor como su misma presencia humana. ${ }^{1}$ En Teresa de la Parra, en efecto, el amor y la melancolía estarán asediando constantemente su existencia, palpitando en el interior de su escritura, intercambiándose, re-inventándose más de las definiciones, nutriéndose de las propias carencias afectivas, vitales y también estrechamente ligados en la alegría, a ese fino sentido del humor, de lo cómico, que hace la "gracia" de su literatura.

La producción ficcional de esta autora, en lucha constante contra las prohibiciones, contra el enrejado moral de la cultura, revela en el plano de la escritura la presencia de un cuerpo deseante, significante, que marca sus deseos, su goce, pero también sus nostalgias y su melancolía. Así en Ifigenia ${ }^{2}$ están los trazos, las huellas de un deseo inconsciente,

\footnotetext{
${ }^{1}$ El testimonio de quienes la conocieron coincide en señalar la fascinación que su personalidad imponía. Así, Uslar Pietri ha observado que "Ana Teresa como siempre la llamamos todos los que la conocimos como amigos, estaba revestida de doble prestigio y de una indefinible fascinación. Era una bella mujer, pertenecía a lo que entonces se llamaba la "alta sociedad". Unía a la gracia y a la belleza física una refinada manera de ser ... Su presencia era inconfundible y dominante. Era imposible no sentirse atraído hacia aquella mujer cultivada, tan llena de gracia y equilibrio". Arturo Uslar Pietri, "Recuerdos de Ana Teresa", en Iconografía de Teresa de la Parra, investigación, recopilación, cronología comentada por Velia Bosch (Caracas: Edición de la Biblioteca Ayacucho, 1948) 47.

${ }^{2}$ Las citas y referencias remiten a Teresa de la Parra, Obra (Narrativa, ensayo, cartas). Selección, estudio crítico y cronología: Velia Bosch (Caracas: Biblioteca Ayacucho, 1982). "Teresa de la Parra: las voces de la palabra" por Julieta Fombona.
} 
plural, contradictorio, que se expresa en la María Eugenia Alonso que viene de París, en su narcisismo, en su voluptuosidad ante el espejo, ante las miradas.

Es la María Eugenia Alonso que se sabe admirada, deseada por Gabriel Olmedo, por Perucho, que se identifica con Mercedes Galindo en una suerte de relación impregnada de un delicado erotismo. ${ }^{3}$ Amor excesivo el de María Eugenia por Gabriel, profundamente melancólico. El deseo, la melancolía, penetran los textos de Teresa de la Parra desde los primeros cuentos ("Historia de la señorita grano de polvo bailarina del sol", "El genio del pescartas" y "El ermitaño del reloj”), a través de la creación de una suave atmósfera onírica, de cierto clima amoroso que involucra a unos personajes escapados del sueño, de lo fantástico, hasta las páginas mismas de Las memorias de Mamá Blanca marcadas de amor y melancolía maternales. Es esa nostalgia que se quiere hacer escritura a través del discurso de las niñas, de la constante apelación a lo oral que está detrás de los cuentos que encantan y seducen a Blanca Nieves. Ya en los primeros cuentos escritos por Teresa de la Parra encontramos la presencia de la melancolía y una cierta concepción trágica del amor y de la vida que lleva a estos fantásticos personajes a una muerte absurda y en ocasiones un tanto grotesca. Se trata de relatos que se ubican en un tiempo-espacio que nos recuerda los cuentos de hadas debido a 1a tonalidad mágica, fantástica que en ellos se percibe y a su incisiva y nostálgica referencia a la infancia, al pasado. Los personajes de estos cuentos son héroes melancólicos, contemplativos, de vida mística o relacionada con algún tipo de actividad espiritual. Así, Jimmy en la "Historia de la señorita grano de polvo bailarina del sol", sumido permanentemente en la contemplación, no piensa sino en el pasado. Su amor, la señorita grano de polvo, tiene los rasgos de su misma ensoñación: etérea, argentina, rostro indefinido y cambiante. Entramos entonces en contacto desde esta primera etapa de la producción narrativa de Teresa de la Parra con la noción de un amor idealizado, imposible, proyección onírica de Jimmy, resultado en gran medida de su misma ensoñación y melancolía. La nostalgia por el pasado es la irremediable aflicción de Jimmy.

El tiempo primaveral estimula o propicia el recuerdo, la nostalgia y la melancolía por ese amor extático, imposible, de la "Señorita grano de polvo" trágicamente devorada por el bostezo de un insecto cuando danzaba "imponderable y como espiritual" a la luz de un rayo de sol. Final trágico y cómico de una relación amorosa sublime que sume a Jimmy en una total melancolía amorosa. ${ }^{4}$ "El genio del pesacartas" se ubica también en

\footnotetext{
${ }^{3}$ La descripción de Mercedes Galindo en Ifigenia coincide en buena medida con los rasgos propios de Mercedes Emilia Ibarra Urdaneta, al parecer "la mujer más influyente en la vida de Teresa de 1a Parra. La personalidad de Emila Ibarra es la misma que corresponde a Mercedes Galindo en Ifigenia. Ella tuvo una formación humanística francesa y fue educada en París ...". Louis Lamaître, Mujer ingeniosa. Vida de Teresa de la Parra (Madrid: Ediciones La Muralla, 1987). La muerte de Mercedes Emilia Ibarra sumirá a Teresa de la Parra durante algún tiempo en profunda melancolía. ${ }^{4}$ Starobinsky observa que a las tres variedades de la melancolía señalada por los filósofos de la antigüedad (una afección melancólica ubicada en el encéfalo, una melancolía generalizada, "es la que la bilis pasa hacia la sangre del organismo por completo, comprendido el encéfalo" y una melancolía de origen digestivo que se propaga hasta el encéfalo "a través de las inhalaciones y los vapores"). Burton, en 1621, sobrevivirá aún rigurosamente a esta división, agregando a ella la melancolía amorosa (que Galiano ignoraba) y la melancolía religiosa, enfermedad más moderna".
} 
ese pasado remoto propio de los cuentos fantásticos. Se trata de un gnomo que rememora a través de relatos fantásticos su lejano esplendor. La tristeza y la melancolía aparecen inicialmente ligadas a la existencia de un grupo de menestreles que buscan asilo en la propiedad de su antiguo compañero de juglaría, ahora convertido en el genio del pesacartas, y se ven despóticamente rechazados por él mismo. Este, en su vanidosa exaltación, caerá al fondo del tintero. La situación se invierte para el genio del pesacartas pues el dueño del tintero - un poeta - al darse cuenta de la ingratitud del gnomo, lo reduce a una gaveta a la par que coloca a los menestreles en un ramo de follaje.

No privan, por supuesto, en este relato, las significaciones referidas a la melancolía o a lo amoroso como en el cuento anterior, pero hay evidentes rasgos de humor irónico y un cierto escepticismo referidos a los sentimientos de amistad y de solidaridad.

En "El ermitaño del reloj" las significaciones de misticismo, de soledad o vida retirada se ponen de relieve a través de la presencia de un "capuchino", personaje que encerrado en un reloj de mesa esculpido en madera, "tenía como oficio tocar las horas" (Obra 415). Prestigiado y orgulloso en su función de dar las horas, Fray Bernabé cultivaba el misticismo y el misterio. Fatigado por el aburrimiento y entusiasmado por un elefante de ébano, decide conocer a la reina de Saba, de quien se enamora. Pero Fray Bernabé no tiene historias maravillosas que contar y la reina de Saba lo despreciará. Es la decepción amorosa. La tristeza y el sentimiento de culpa invadirán el espíritu del fraile, quien finalmente, abatido por la desolación y la desesperación, al darse cuenta que "su trabajo y su sacrificio diario no eran sino de risa" termina ahorcándose.

Final -insistimos- marcado por una tragicidad de relieves cómicos o grotescos. Como en el relato titulado "La señorita grano de polvo" el amor no es sino un espejismo al final del cual está la decepción, el absurdo cómico, el melancólico vacío, ${ }^{5}$ la tragedia, la muerte grotesca. Teresa de la Parra ama los itinerarios imposibles, imaginarios. Viajará mucho ciertamente, pero también lo hará a través de la escritura, construyendo vidas, trayectos, espacios que no le pertenecen. El Diario de una caraqueña por el Lejano Oriente es uno de los diarios de viajes en los que la ficción simula trayectos no recorridos físicamente pero anhelados con profunda melancolía.

Hay siempre en Teresa de la Parra el deseo de ser ese otro que alguna vez soñamos, difusamente escondido en las confidencias de la memoria, en la posibilidad de la ausencia, en la mudanza que ésta encarna. El viaje significa este deseo de ser otro, de cambiar la piel al mudar de lugar. Es esa experiencia de imaginar otro espacio del yo lo que fascina a nuestra escritora.

El Diario de una caraqueña por el Lejano Oriente, es una aventura de iniciación casi novelesca, por unos territorios que seducen en su extrañeza, en su diferencia, en su

Jean Starobinsky, "La mélancolie, au jardin des racines grecques", Le Magazine Littéraire, 244 (París, julio-agosto, 1987).

${ }^{5}$ La melancolía - dice Freud - "se caracteriza psíquicamente por un estado de ánimo profundamente doloroso, una cesación del interés por el mundo exterior, la pérdida de la capacidad de amar, la inhibición de todas las funciones y la disminución del amor propio". Sigmund Freud, "Duelo y melancolía", Obras completas, Tomo 2, (3 a edición). Traducción Luis López Ballestero (Madrid: Ediciones Biblioteca Nueva. 1973) 2091. 
parcela de cosa no vivida. Imaginar el otro, ese otro de la escritura, de esa memoria melancólica por imposible, por haberse perdido ya, será siempre en Teresa una experiencia permanente y seductora. La melancolía de este Diario tiene, pues, la ambivalencia de la mirada narcisista y el sentido amoroso de la relación especular. Viaje a ratos nostálgico por un afuera desconocido (Japón, China), por ciudades cosmopolitas y paisajes exóticos (Nueva York, Chicago, Yokohama, Tokio, Shanghai) pero viajes también al interior de un yo que se extravía y se fascina en la imaginación y nominación de sus deseos.

Hay una descripción objetiva de lo público y una ensoñación de lo privado, impregnada del recuerdo, en la que se desplaza la contemplación, la mirada retrospectiva, imbuida de extrañeza y de melancolía. ${ }^{6}$ Si la descripción de ciudades, objetos y parajes públicos es exteriorista y privilegia la nominación de edificios, monumentos o construcciones civiles, la ensoñación privada privilegia la nominación de grandes espacios naturales en los que la imaginación se abisma y se despliega en extensión e intensidad: el mar, la montaña, sus colosales ascensos, descensos, precipicios, los bellos caminos por los que se desliza el tren.

Con Ifigenia estamos ya en presencia de una novela del amor imposible, de allí su intensidad imaginaria y vital, de allí también su profunda melancolía. Una melancolía que sueña, que contempla y conduce a María Eugenia Alonso hacia una relación amorosa tan ideal, tan ligada a la identidad de su propio cuerpo y "ánima" que deviene trágica, imposible. La búsqueda amorosa y melancólica de María Eugenia es la búsqueda narcisística y especular de su propia alma. Aún cuando este amor está impregnado novelescamente de los humores de la heroína, de su sensualidad e ingeniosidad irónica y vital, de una cierta cotidianidad de su cuerpo y sus deseos, este amor (que deberíamos escribir con mayúscula) está constantemente girando en torno a María Eugenia, a su desesperada melancolía de sí misma. El amor de María Eugenia Alonso, novelesco y cotidiano al parecer, pretextado en una relación imposible, es en el fondo un amor literario, el amor de Narciso, de Romeo y Julieta, porque su verdadera identidad es especular, reflexiva, literaria.

La ficción alterna, dual, de las cuartillas de María Eugenia, localizadas en el "doble fondo de su armario de luna", se desliza siempre hacia esa melancolía ideal, propia de los grandes héroes literarios, hacia la satisfacción de unos deseos más allá del deseo. La imagen amorosa que persigue María Eugenia, con la melancolía de algo perdido o extraviado en un tiempo anterior es la imagen de un yo ideal. Ese otro yo, a la vez extraño e idéntico, ligado a identificaciones imaginarias, narcisistas, a resonancias familiares y literarias en las que pesa el prestigio y la autoridad moral de figuras amadas por la autora: la madre, el padre, desaparecido a temprana edad, la amiga muerta (Emilia Ibarra), Teresa de Avila, Sor Juana Inés de la Cruz, la Madre Teresa, monja exclaustrada, cuyo conocimiento personal durante su infancia tanto la impresionara, Teresa Carreño.

\footnotetext{
${ }^{6}$ Para Kristeva "el melancólico es un extranjero en su lengua materna. Ha perdido el sentido el valor- de su lengua materna .... La lengua muerta que habla y que anuncia su suicidio oculta una cosa enterrada viva. A ésta no la traducirá para no traicionarla: quedará enmurallada en la "cripta del afecto inexpresable". Captado analmente, sin salida". Julia Kristeva, Soleil Noir. Dépression et mélancolie (París: Éditions Gallimard, 1987) 64-65.
} 
La pasión de María Eugenia, que la torna ensimismada, melancólica, es la pasión por la escritura y por la lectura, suerte de espejos en los cuales ella se mira, se busca, se desea. Como a Don Quijote, parece extraviarla la lectura de novelas (románticas). Es el universo de un tiempo como detenido, que transcurre en la casa colonial, el que genera la tristeza y la melancolía de María Eugenia. Es el tiempo del calado de la Abuelita y la tía Clara, de la lluvia y los postigos, de los cirios votivos. Realidad y tiempo un tanto fantasmales que se oponen radicalmente al tiempo y experiencias en Europa, de sus andanzas en París.

María Eugenia está triste por haber llegado, por haber anclado en este tiempo espeso y religioso, como congelado, de la casa colonial. La carta a Cristina de Iturbe y el diario revelan esta otra situación emocional opuesta a la alegría de París, de una "señorita" ahora "presa" del fastidio y la desazón espiritual. A la idea de los viajes y la libertad de María Eugenia la Abuelita enfrentará siempre los propósitos de una educación virtuosa, y de un "buen matrimonio". A la tristeza de haber llegado se suma en María Eugenia la melancolía que resulta de la contemplación de este oscuro futuro doméstico que le propone la Abuelita, esa "resignación dulce y benigna" que seduce a los hombres del trópico. El programa que ésta le propone: "Tratar de ser lo más intachable posible", se extendía hacia la triste felicidad del matrimonio.

En esa casa familiar, en la que todo parece detenido e inmovilizado por el fastidio, será la escritura la pasión de soledad que nombrará los sinuosos rostros del amor y la melancolía. Pasión exaltada, la escritura (de la carta, del diario) revela y refleja esa otra trama de interioridad de una María Eugenia que se resiste y se revela contra las convenciones de lo doméstico-familiar. Interioridad de una heroína que secretamente se indaga y se ama a sí misma en las espejeantes palabras y rostros que teje la ficción. Identificación y rechazo, amor y miedo, están presentes en la relación de María Eugenia con la Abuelita y la tía Clara. Reconoce en ellas afectos pero no quiere repetir o reflejar sus imágenes, la experiencia amorosa, por ejemplo, de una tía Clara "dejada" por su novio, convertida en esa solterona que al decir de Gregoria "parece la pobre un mismo cirio de esos que llevan el Jueves Santo en las procesiones ..." (Obra 91).

Ante todo, pues, María Eugenia se ama a sí misma y la relación, el conocimiento de Mercedes Galindo y Gabriel Olmedo, se constituyen desde el primer momento en un modo de afirmación de su propia identidad personal, en una vía regia de seducción que le permite mostrar(se), lucir(se) sus cualidades físicas y espirituales. ${ }^{7}$ Desafiada, como retada inconscientemente en su condición de mujer bella por Mercedes Galindo y por Gabriel Olmedo, frente a ellos María Eugenia se sentirá superior, resistiéndose a ser

\footnotetext{
${ }^{7}$ Baudrillard distingue la seducción del amor: "Lo propio de una pasión universal como el amor reside en ser individual, y en que cada uno se encuentre solo en ella. La seducción es dual: no puedo seducir si no estoy a mi vez seducido, nadie puede seducirme si no está a su vez seducido .... La seducción es un desafío: saca a cada uno de su subjetividad, liberándole de todos los posibles celos .... Toda la fascinación del mundo está concentrada en el instante de la seducción, y no hay término exterior. Mientras que el amor implica siempre algo territorial y exclusivo. Amar a alguien es aislarlo del mundo, es borrar sus huellas, desposeerlo de su sombra, arrastrarlo a un porvenir mortífero". Jean Baudrillard, "El maligno genio de la pasión", Revista de Occidente, 15-16 (Madrid: Edición Fundación José Ortega y Gasset, agosto-septiembre, 1982) 24-25.
} 
seducida. Y será precisamente Mercedes Galindo, mediadora de su relación con Gabriel Olmedo, quien, a la vez que estimula las simpatías indicando las sobradas virtudes de Olmedo, señala melancólicamente, desencantada, la casi imposibilidad de amor, dadas las dificultades de encontrar la pareja ideal.

La identidad Mercedes Galindo - María Eugenia parece sostenerse en esta propensión común al fracaso amoroso, a la melancolía. En efecto, las palabras de Mercedes Galindo subrayan su concepción melancólica del amor, su actitud de mujer resignada a una relación de caridad y de compasión con su esposo Alberto, a quien no ama. En la posible relación amorosa de María Eugenia y Gabriel Olmedo, Mercedes Galindo cree ver realizada la pareja ideal, esa felicidad amorosa del "âme soeur" para ella definitivamente perdida. ${ }^{8}$ En lugar del acuerdo y la armonía Mercedes Galindo vive el amor como sufrimiento y como sacrificio. El espacio ideal de la novela pastoril (Paul y Virginia) con el que Mercedes se representa el amor está ocupado por la tragedia. De este modo, lo que nos cuenta Ifigenia a través de la confidencia amorosa de Mercedes es la misma nostalgia de amor de María Eugenia, la imposición posterior del sacrificio, la renuncia, la conversión hacia la misma que vivirá María Eugenia. Una es reflejo y proyección de la otra. María Eugenia cuenta su historia a Cristina, hace de ella su confidente, la escucha de su melancolía. También Mercedes hace de María Eugenia su confidente al narrarle su fracaso, sobre el cual se dibuja la experiencia de María Eugenia. También esta deberá aceptar a un hombre que no ama. Suerte de historia amorosa que refleja y copia otra historia fundada en los mismos conceptos de renuncia y melancolía, en la misma decepción amorosa, la novela deviene así diálogo de espejos enfrentados.

La idea del amor resulta una suerte de metáfora del vacío, un no-lugar. En realidad, la posibilidad del amor, de su realización, llena a María Eugenia de un miedo extraordinario que la impulsa a rechazar a quienes la pretenden. Cuando el poeta colombiano se le acerca en el barco que la trae a Venezuela y después de un cierto asedio amoroso quiere darle un beso, María Eugenia lo rechaza bruscamente, hasta el punto de que el poeta pierde sus lentes y queda solo, trastabillando, sumido en la ceguera, en la oscuridad de la cubierta del barco. San Nicolás, la hacienda donde debe retirarse María Eugenia, será un espacio de melancolía, de soledad, de reflexión interior. Separada de Mercedes Galindo y de Gabriel Olmedo por su familia, en esta casa de campo María Eugenia acepta que ama intensamente a Gabriel Olmedo y espera ansiosa y nostálgicamente su re-encuentro. La idealidad y melancolía de su pasión se manifestará en sus constantes ensueños y visiones en los que su relación con Olmedo se recrea en todo un contexto de rasgos místicos y fantasmales.

\footnotetext{
${ }^{8}$ Hay en esta noción del amor melancólico cercanía con lo que Benjamín llama "amor platónico": un amor opuesto al matrimonio: "que guarde intacto, que proteja el nombre de la amada, es la sola expresión verdadera de la tensión, de la inclinación a la lejanía que se llama amor platónico. Para él la existencia de la amada procede, como rayo, desde el núcleo incandescente del nombre y de éste procede incluso la obra del amante. Y así la Divina Comedia no es otra cosa que el aura en torno al nombre de Beatrice: la exposición más poderosa de que todas las fuerzas figuras del cosmos proceden del nombre que surge a salvo del amor". Walter Benjamin, "Amor platónico", Discursos interrumpidos. Prólogo, traducción y notas: Jesús Aguirre (Madrid: Ediciones Taurus, 1982) 143.
} 
La alusión a Dante y su pasión por Beatriz subrayan este carácter sublime y refieren así el paradigma de esta invención amorosa. La escritura, una vez más, es diálogo, ata y libera. Mecanismo de indagación interior, la escritura revela la melancolía de esta pasión y los desgarramientos de una subjetividad que oscila entre la fantasía y la desilusión. La carta se piensa como la posibilidad de unión, de comunión con Gabriel. Una posibilidad decepcionada. María Eugenia no recibe la esperada carta de Olmedo y en su lugar llegan los cinco tomos de las tragedias de Shakespeare. Se da de este modo una suerte de desplazamiento o de usurpación de la carta y del sentido de "comunicación" y de felicidad o bienestar que ésta implica por la escritura de la tragedia y sus connotaciones de "incomunicación" personal, de ruptura, de infelicidad.

La referencia a Shakespeare, a la escritura de la tragedia, viene de nuevo a corroborar este clima de una pasión ideal, a la vez que prefigura la tragedia amorosa de María en Ifigenia la concepción del amor sobre el modelo intertextual de la tradición literaria que se inicia con el Roman de Tristán y que hace de la nostalgia, del recuerdo, de la pérdida irremediable, elementos constitutivos, nutrientes fundamentales de esta tradición. ${ }^{9}$

El amor de María Eugenia por Gabriel Olmedo se transforma en una espera angustiada e inútil y, por lo tanto, en sufrimiento triste y melancólico que la impulsa a la constante búsqueda interior. Encontramos acá uno de los rasgos diferenciadores de Ifigenia con respecto a la tradición de la novela romántica (Peonía de Romerogarcía o En este país de Urbaneja Achelpohl para sólo citar dos títulos representativos) en la que la problemática amorosa expresada en un lenguaje melodramático y gastado deviene finalmente en un idilio de "carta postal", para usar la expresión de Rougemont. ${ }^{10}$

Es precisamente la expresión de un dolor, de una subjetividad desgarrada que incesantemente intenta enunciar la separación, la espera, más allá de los estereotipos del modelo romántico, lo que le otorga a Ifigenia su lugar de diferencia, su modernidad, en el contexto de la novela amorosa venezolana y latinoamericana. Hemos hablado de la existencia en Ifigenia de un discurso de "amor ideal" en la medida en que éste resulta

\footnotetext{
${ }^{9}$ La concepción del amor en Ifigenia se contamina sin duda de estas diversas manifestaciones del amor-pasión que ha estudiado Rougemont a partir del mito del amor cortés en las que se concibe el amor como una realidad soñada, un ideal, un sufrimiento. Íntimamente ligado a la "deliciosa tristeza", al "spleen" vital, o a la melancolía, el amor desea el obstáculo, las dificultades. "Considérese nuestra literatura. La felicidad de los amantes sólo nos emociona por la espera de la desgracia que acecha. Hace falta esa amenaza de la vida y de las realidades hostiles que la alejan hacia un más allá. La nostalgia, el recuerdo y no la presencia, nos emocionan ... El amor feliz no tiene historia en la literatura occidental ... Si ahora recorremos los textos de los grandes místicos españoles, Santa Teresa y San Juan de la Cruz, en el siglo XVI, volvemos a encontrar en ellos, hasta en sus más preciosos matices, la retórica del amor cortés". Denis de Rougemont, El amor y occidente ( $2^{\mathrm{a}}$ edición). Traducción Antoni Vicens (Barcelona: Editorial Kairos) 54-55 y 164. ${ }^{10}$ Hay en Ifigenia, al contrario de este amor de "carta postal", rasgos propios de un amor ideal, divino, en el sentido platónico; "tal es el amor plátonico: delirio divino, transporte del alma, locura y suprema razón ... El Eros es el Deseo total, la Aspiración luminosa a la extrema exigencia de pureza que es la extrema exigencia de Unidad. ... Platón vinculaba el Amor a la Belleza. Pero la Belleza que él entendía era en principio la esencia intelctual de la perfección increada: la idea misma de la excelencia". (Rougemont 61-75).
} 
impregnado de esa suerte de enfermedad divina que es la melancolía, de esa enajenación que se convierte a ratos en María Eugenia en un verdadero transporte y locura del alma. Es entonces la ausencia y separación de Gabriel Olmedo lo que transforma su deseo amoroso en melancolía de amor. Esta a su vez se verá estimulada por la incertidumbre que generan los insidiosos comentarios de María Antonia en el inquieto ánimo de María Eugenia en torno al supuesto matrimonio de Gabriel con la hija de un acaudalado e influyente hombre de gobierno. Los paseos al río acompañada de su primo Pedro José (Perucho), seducido por los encantos de María Eugenia, el contacto íntimo con la naturaleza, conducen esta melancolía de amor al ritmo y grado del éxtasis lírico. Como Narciso encantado por sus propios reflejos, María Eugenia se entrega a una contemplación que la devuelve transfigurada en el éxtasis de su pasión. El río, como los espejos de su cuarto, como la carta a Cristina de Iturbe o el diario, le proponen la imagen extrañada, enajenada de sí misma, a la vez que le permiten multiplicar y prolongar los rostros y preguntas en torno a su compleja identidad.

En esta perspectiva del narcisismo, el análisis revela que María Eugenia parece melancólicamente enamorada de su imagen ideal, de esa belleza que admira en las estatuas griegas, símbolo por lo demás de la perfección, de la armonía total. ${ }^{11}$ Se reconoce inicialmente, en la bella joven que se pasea por las grandes tiendas de París, que compra los más bellos vestidos y es admirada y elogiada por todos. A esa vida encantada de los espejos de un París moderno, refinado, de tono exquisito y elegante no podrá volver, pues, despojada de su herencia; no tiene fortuna, su desdicha, como la de "El Desdichado" de Nerval, es también la de una desheredada que busca en la escritura nombrar su imagen perdida, un exilio o extravío interior. ${ }^{12}$

Frente a la desposesión e incomprensión de la familia y el amor de un hombre que abandona y se decide por el matrimonio con otra mujer, el exilio de María Eugenia será el de esa imagen narcísica que le devuelve el agua de ese otro río, insondable también, reflexivo, de su diario, sus cartas, sus impresiones personales, la escritura. Por otra parte, el amor de María Eugenia por Gabriel es tan puro, tan transparente, tan místico, que es un amor narcísico y sacrificial, de goce en la desposesión y el abandono: "Tú eres el dulce Mesías de mi alma, Gabriel, y tu amor es el agua del Jordán que me ha redimido para siempre de las prisiones del Limbo" (Obra 154) le dice en una carta que le escribe al borde del río y que luego termina por romper.

Las ideas de la carta pasan después a un soneto en el que los personajes trágicos de Shakespeare, Romeo y Julieta, son su propia máscara y la de Gabriel Olmedo. Este afán

\footnotetext{
11 "Estamos condenadas a amar" dice Green. "El amor comporta, según Freud, un empobrecimiento narcísico. Pero C. David ha hecho observar justamente que el estado amoroso exalta el narcisismo. ... El narcisismo es el Deseo del Uno. Utopía unitaria, totalización ideal que viene a ponerlo todo en cuestión: el inconsciente en primer lugar .... El Uno reenvía al Doble". André Green, "Un, Autre, Neutre" en "Narcises", Nouvelle Revue de Psychanalyse 13. Printemps (Paris: Éditions Gallimard, 1976) 53-58.

${ }^{12}$ Kristeva, a propósito de la melancolía en Nerval, señala: "Désherité, privé, de ce paradis perdu, il est infortuné; cependant l'écriture est l'étrange moyen de dominer cette infortune en y installant un 'je' qui maitrise les deux côtés de la privation: les ténèbres de l'inconsolé aussi bien que le baiser de la reine". (Kristeva 155-157).
} 
o necesidad de construirse una como imagen ideal de sí y de su amor, a través de la escritura y de los objetos o personas que reflejan narcísicamente un cuerpo, nos lleva a ver en María Eugenia una suerte de nostalgia o melancolía de otro mundo u otro espacio vital y psíquico. ${ }^{13}$ La carencia de libertad económica y espiritual y la falta de un respuesta amorosa por parte de Gabriel Olmedo hacen hostil el presente y estimulan esta melancolía de otra vida que está detrás de la alusión a la tragedia de Shakespeare. Lo que María Eugenia ama es ser la flor de Narciso. Es ese su otro mundo ideal. Ese Narciso Gabriel Olmedo en el que se contempla y se ama, en el que busca su perfección andrógina. Una relación, un otro lugar que se mutará en un itinerario de expiación o purificación mística ${ }^{14}$ de entrega sacrificial que habrá de culminar en ese acto final de la tragedia su muerte por amor, en el amor-que es el matrimonio con César Leal.

María Eugenia morirá en su amor para entregarse a esa "deidad terrible y ancestral: Dios milenario de siete cabezas que llaman sociedad, familia, honor, religión, moral, deber, convenciones, principios" (Obra 310). La referencia a la tragedia de Shakespeare y la inserción de personajes bíblicos marca esta aspiracón de un más allá sobre el que se va diseñando una María Eugenia cada vez más "cautiva" de la soledad, de su tristeza, de los principios morales a los que parece acceder, que rigen la vida familiar. Las discusiones y conflictos con una Abuelita escandalizada de la mundanidad de María Eugenia se truecan en imprecaciones de soledad y melancolía, en renuncia y acceso, de este modo, al universo "religioso" cerrado de la Abuelita y la tía Clara.

Decepción y resignación van configurando el espacio de una melancolía que se refugia en el recuerdo de la infancia y adolescencia, de un tiempo de ilusiones, perdido irremediablemente, compartidos con Cristina de Iturbe a través de los años de internado en el Colegio Sagrado Corazón. ${ }^{15}$

\footnotetext{
${ }^{13}$ La nostalgia de otro mundo es lo que define, para Murena, la melancolía: "Esa melancolía es la nostalgia de la criatura por algo perdido o nunca alcanzado, nostalgia por un mundo que falta de modo irremediable, pues si no fuera así la herida por la que mana la poesía podría restañearse: aunque esa nostalgia se expresa en relación a objetivos mundanos, éstos no son nunca más que ocasiones tomadas para expresar la nostalgia fundamental respecto a lo imposible, porque la esencia del arte es nostalgia por el Otro Mundo". H. A. Murena, La metáfora y lo sagrado (Barcelona: Editorial Alfa, 1984) 25-26.

${ }^{14}$ R. Díaz Sánchez señala que la propensión de Teresa de la Parra "fue, pues, la de idealizar la materia y por ello no sería extraño el que en su experiencia en el mundo de los afectos llega a producirle decepciones capaces de herir su sensibilidad hasta el punto de producirle lo que podríamos llamar un complejo de idealización del amor, o lo que es lo mismo, de misticismo". Ramón Díaz Sánchez, Teresa de la Parra (clave para una interpretación) (Caracas: Ediciones Garrido, 1954) 25.

${ }^{15}$ Es el nombre del mismo colegio en el que estudiara Terese de la Parra en Valencia, España. Los datos aportados por la narración, que recuerdan los años de amistad de María Eugenia con Cristina de Iturbe presentan puntos de coincidencia con la época de Teresa interna en el Colegio del Sagrado Corazón. Entre 1902 y 1903 ingresa al internado de las Madres del Sagrado Corazón en Godella, Valencia (España) en el cual permanecerá hasta 1909 cuando regresa de nuevo a Venezuela. Véase Velia Bosch, "Cuadro bibliográfico y cronológico", Esta pobre lengua viva (Caracas: Ediciones de la Presidencia de la República, 1979) 172; y de la misma Velia Bosch, Teresa de la Parra. Conversación biográfica (Caracas: Alfadil Ediciones, 1986).
} 
Es la memoria nostálgica que estimula la carta-respuesta de Cristina en la que se le señala su gran felicidad por la pronta realización de su boda. Para esta María Eugenia melancólica, asfixiada espiritualmente por la imposibilidad de su amor con Gabriel Olmedo y por el cerco autoritario de la familia, la carta se le presenta en un tono festivo "del más horrible gusto". La noticia de la boda y la alegría que ésta implica para Cristina, significa en el fondo para María Eugenia la ruptura de una identificación y una intimidad sostenidas durante largos años a través de comunes confidencias y complicidades, en el espíritu de melancolía y en el amor y gusto por las mismas cosas.

Cristina, que era espejo de María Eugenia, opta de pronto por el matrimonio, por otra vida; entonces la identificación especular se rompe. Afectada por su amor propio, la herida es de algún modo una herida narcísica. Lo que María Eugenia ve romperse o morir en la carta es una parte de ella misma. Y esta decepción vuelve aún más enfática en María Eugenia su concepción escéptica y melancólica del amor. El amor, llegará a decir más tarde, "no existe" (218), forzada por acción del medio familiar a contraer nupcias con Céasr Leal. Todo el encanto por la vida que la heroína encontraba en la vida mundana, llena de alegría por seducción y tentativas que le ofrecía el París moderno, de las modas, ese goce de sentirse bella y admirada, se ha venido desvaneciendo y las resistencias mismas ante las fuertes prohibiciones del grupo familiar se han trocado en renuncia y melancolía.

Una renuncia de profundas connotaciones místicas y una melancolía depresiva que parece ahora soñar la nada, el vacío, la muerte. ${ }^{16}$ Pasamos así en Ifigenia de una escritura trabajada por la pulsión de vida, por el goce y el sentimiento de euforia que se traslucen en el narcisismo de una María Eugenia libertina, de vida parisina, a esta escritura cada vez más accionada por la pulsión de muerte, por esta seducción de la nada que revelan ahora las palabras de una heroína desencantada, profundamente sumida en el dolor y en el escepticismo amoroso. Escepticismo amoroso y melancolía pasan a configurar cada vez más sensiblemente la dimensión subjetiva, "semiótica" (pulsional) de una escritura que en su fulguración simbólica nombra, sin embargo, carencias, deseos, rechazos, miedos, sueños ligados sin duda a los estratos más internos y secretos de la vida de Teresa de la Parra. ${ }^{17}$ Nos referimos a este trabajo del inconsciente (orden de lo semiótico) que penetra

\footnotetext{
${ }^{16}$ Para Kristeva, "Es posible hablar de un conjunto melancólico depresivo ... La melancolía sería en suma, una perversión innombrable, blanca ...". La depresión femenina para esta psicoanalista y semióloga "es más frecuente y en cierta medida más difícil de atravesar en razón de la adherencia frecuentemente insuperable de una mujer frente a su madre".

Constato también el papel determinante de la vinculación con la madre en todas las formas de melancolía". Julia Kristeva, "Les abîmes de l'âme". Entrevista a Julia Kristeva por Dominique Grisori en Le Magazine Littéraire 244 (París: julio-agosto, 1987). En otra parte esta analista nos indica que en realidad "Lo que el amor viene a especificar, es lo que Freud había descubierto al final de su vida, es decir, la pulsión de muerte. Provisoriamente o por toda la vida, como decía Kafka". J. Kristeva, "Entretien", Cahier de Recherches 34/44 (S.T.D. 13) (París: Université de Paris VII, 1964).

${ }^{17}$ Es profundamente reveladora en este orden la numerosa correspondencia personal de Teresa de la Parra. Así, en carta que escribe a Gonzalo Zaldumbide, nos parece terriblemente sincera su apreciación del amor: "Siento el más profundo desprecio por esa cosa que llaman amor, que es
} 
la práctica textual a través de esta obsedida nominación de la melancolía y de un sentido del amor ligado a ese errancia y desamparo que se deja leer en importantes momentos de su correspondencia privada. Lo que Ifigenia enuncia es entonces la imposibilidad del sentimiento amoroso, incapaz de superar la idealización narcísica y mística del propio yo. La decepción amorosa es el otro lado de un sentimiento que es asumido como melancolía y fantasía de sí, es decir, especulación (y espejismo), desdoblamiento del yo. María Eugenia no podría decidirse por el amor de Gabriel Olmedo, por la promesa de libertad o de salvación que le parece inherente, porque se ama demasiado a sí misma como para entregarse riesgosamente a otro. ${ }^{18}$

Prefiere, por lo tanto, condena del matrimonio con César Leal a una liberación fuera de lo institucional que la enfrenta a sus propios fantasmas, a la autoridad de ese Padre omnipotente, también madre amada y odiada que es la Abuelita. Idealizado, melancólico, sublime y finalmente convertido en tragedia, el amor de María Eugenia por Gabriel Olmedo pasa por el desencanto e incluso bordea lo abyecto (recordemos el desprecio y rechazo de María Eugenia con respecto al beso: "como costumbre-dirá-puede llegar a ser antihigiénico") (Obra, 220). El amor es, pues, este espejismo que la escritura de la novela y el discurso de María Eugenia en particular remiten siempre a ese otro discurso del amor trágico e imposible que se mira y se recrea en la muerte: Leandro y Hero, Ofelia y Hamlet, Tristán e Isolda, Romeo y Julieta.

En efecto, cuando los amantes se reencuentran en el lecho de muerte del tío Pancho, María Eugenia sabe ya que su amor es una nostalgia del pasado, añoranda incluso de la muerte, melancolía. No hay en Ifigenia la estructuración de un discurso amoroso como diálogo con el otro, sino diálogo de un yo escindido que se contempla y se reinventa en una escritura especular y seductora en su deslumbrante pluralidad de sentidos. María Eugenia ama escribir, escribirse y desde su íntima desgarradora pasión parece insinuarnos constantemente que el amor es sólo una mentira sublime, más allá de la cual sólo queda

brutal y salvaje como los toros del domingo con los pobres caballos destrozados. No quiero sino ternura, eso que crees que yo no conozco y en lo cual soy maestra especialista imposible de equivocarse ni engañar ... Tengo en general ... miedo a ti y horror a los demás hombres, jah si supieras quererme con alma de mujer!..." "Cartas de Teresa de la Parra a Gonzalo Zaldumbide en Obra: 531-532. En su corresrondencia a Rafael Carías podemos leer esta exaltación de la melancolía: “... esos momentos de melancolía, los mejores quizás de la vida porque sentimos la nostalgia de lo grande y de lo bello que creemos podemos encontrar más allá, en otro ambiente, en otro género de vida y que en realidad sólo está, sin que lo sepamos en el fondo de nosotros mismos". Carta a Rafael Carías fechada en París el 16 enero 1931 en Cartas a Rafael Carías (Alcalá de Henares: Talleres Penitenciarios, 1957) 122.

${ }^{18}$ Para Kristeva "En el amor se produce un importante relevo del narcisismo, de manera que la relación establecida por Freud entre amor y narcisismo no debe hacernos olvidar su diferencia esencial ¿No es cierto que el narcisista, como tal, es precisamente alguien incapaz de amar? ... Sujeto del reflejo (a la vez que de la muerte) Narciso no está en la dimensión objetal o sexual. No ama ni a los jóvenes, ni a las jóvenes, ni a los hombres ni a las mujeres. Ama. Se ama: activo y pasivo, sujeto y objeto. De hecho, Narciso no está completamente desprovisto de objeto. El objeto de Narciso es el espacio psíquico; es la propia representación, la fantasía .... Julia Kristeva, Historias de amor (México: Ediciones Siglo XXI, 1987) 28-29 y 100. 
su entrega sacrificial, la absoluta y purificadora divinidad de la muerte. Si Ifigenia es escritura nostálgica y melancólica de la muerte, Las memorias de Mamá Blanca son por el contrario nostalgia y melancolía de la infancia. Una infancia-paraíso que la escritura ama y desea recuperar a través de un lenguaje que se realiza como diálogo y tejido plural de la memoria. La misma escritura va trazando y organizando lo límites de un universo circunscrito por la memoria por el recuerdo nostálgico y melancólico de una edad feliz. ${ }^{19}$

Pérdida del reino, la escritura de Las memorias ... oscila entre la alegría de un presente que exalta la infancia como momento privilegiado del ser y la tristeza que produce su tránsito y su clausura. La visión de una narradora anciana que reconstruye sus Memorias desde su vejez en las voces de las propias niñas, la epopeya de ese tiempo crucial que es la infancia, genera este sentimiento de melancolía propio de recuento de la vida ya transcurrida. Hay, sin embargo, una alegría de volver a vivir, un goce de la imaginación que crea, pero hay también un dolor del regreso. ${ }^{20}$ La nueva sensibilidad que expone Las memorias de Mamá Blanca viene de esta capacidad del texto de fijar dentro de sí los límites de su propia creación, a través de la organización de un universo de fícción autónomo. A diferencia de la novela venezolana del realismo costumbrista o criollista que establecía, a través de referentes textuales, cierta dependencia del texto con realidad, circunscribiendo o limitando así el rol de la imaginación, en Las memorias ... es la infancia misma la que se constituye en sujeto de la enunciación, a partir de lo cual la la escritura se rehace continuamente en un diálogo que apela a la participación del lector. Este estará siempre invitado al juego.

Estamos en presencia, entonces, de otra concepción de el espacio narrativo y de un nuevo diseño de la estructura novelesca. El recuerdo,la memoria de la infancia, rigen este otro diseño fundado en un juego y diálogo de lenguajes que recupera y reinventa el rol de la oralidad, convertida ahora en una praxis significante fundamental. El amor y la melancolía están estrechamente ligados en Las memorias ... al sentimiento de pérdida frente a la condición de madre (la maternidad) y frente a la infancia. Teresa de la Parra ama y escribe con nostalgia y melancolía la madre que no es, que no será, y la niña que ha dejado de ser. De fragmentos, de trazos de recuerdos organiza un vacío, una carencia, una nada. Entre el tejido de lo que se recuerda, matizada también de humor y alegría, se

\footnotetext{
${ }^{19}$ En esta perspectiva de la re-invención de una memoria cifrada en la melancolía de un pasado que sigue las pautas de la imaginación y el deseo, no sin fundamento se han establecido relaciones entre Las memorias ... y la producción de Marcel Proust. Proust, en efecto pensaba que "No hay melancolía sin memoria ni memoria sin melancolía. Los optimistas felices son incapaces de soñar 'vidas anteriores"'. Citado por Gilles Barbedette en "Une question de rat", Le Magazine Littéraire 244 (París, julio-agosto, 1987) 19.

20 "Nostos" - dice Bellour- "refiriéndose a la relación nostalgia-melancolía presente en autores y textos fundamentales de la literatura francesa desde Rousseau hasta Roland Barthes de la Chambre claire "es el dolor del regreso. Y este dolor como imprescritible condición del goce". ... El niño para Bellour en otra literaturas europeas no aparece afectado de esta inmaterialidad ideal y herida con que se muestra en la literatura francesa. Raymond Bellour, "Nostos, melancolía", Le Magazine Littéraire 244 (julio-agosto, 1987). Es interesante observar la cercanía de Teresa de la Parra con esta imagen y concepción del niño y de la infancia en Las memorias ... desde su familiaridad y estrecho contacto con la literatura francesa.
} 
dejan entrever los deseos y se escuchan sutilmente las quejas, los silenciosos lamentos. Identificándose así con una infancia que desaparece y se hace nostalgia y melancolía y con una Madre generadora, Teresa de la Parra funda en la narrativa venezolana ese otro espacio simbólico, inexistente antes, que reconocemos en las voces de las mujeres de los niños, de los campesinos. Discursos que no habían sido enunciados desde el lugar de sujetos que les otorga Teresa; y, por lo tanto, no tenián cuerpo ni deseos. Recubiertos, por el contrario, por el sentimentalismo romántico y por estereotipos retóricos, estos discursos no podían estructurar un espacio original.

La estructuración discursiva de Las memorias de Mamá Blanca estará siempre contaminada y penetrada por deseos de sujetos (personajes) que desde la nominación plurilingüe y heterológica de la novela enuncian también sus poderes simbólicos y sus diferencias. Decir el lugar de la madre lugar de la infancia es en Las memorias de Mamá Blanca decir, por lo tanto, el lugar de un margen, de un dolor. ${ }^{21}$ Figuras no reconocidas simbólicamente, como sujetos en nuestra tradición literaria, el amor y la melancolía que la madre y el niño traen al texto estarán ligados tanto al sufrimiento, al desgarramiento interior, como al juego y al humor. De allí la profunda ambivalencia que configura esta escritura que subvierte esquemas y valores y enuncia márgenes, afectos, deseos, dolores.

Hay entonces en este texto un goce melancólico, pudieramos decir, de la palabra que conquista un nuevo espacio a través de una ficción que es un auténtico teatro del Ego.

Lucha contra las prohibiciones, contra las normas de una razón simbólica y todopoderosa, la escritura de Las memorias designa en la melancolía la tristeza por la pérdida de un tiempo y un espacio de goce anteriores a la Ley, al Padre simbólico, a la civilización. De allí el gozoso elogio de esa naturaleza grata, placentera, que es Piedra Azul, inscrita en un tiempo y lugar, en un orden, anterior a la Cultura. Desaparecido, muerto en alguna anónima batalla o guerrilla del pueblo, el amor de Vicente Cochocho es un amor anti-institucional en la medida en que es anterior al matrimonio, a la civilización de la propiedad privada y por lo tanto, exento de celos y rivalidades. El recuerdo o memoria de este personaje no puede sino estar escrito en melancolía. Vicente Cochocho es además la subversión de una ética y una estética fundadas en la Norma, en la violencia de la Ley. La infancia, como Cochocho, es también un tránsito que participa de la inocencia, la maternidad y la ternura. Sólo puede escribirse su memoria con el encanto de esa escritura que otorga vida y señorío a los seres y cosas humildes, pequeños, lejanos.

${ }^{21}$ Lo irrepresentable de la melancolía - nos propone Buci Glucksmann "no es otra cosa que la nada del sujeto mismo. "Parvus sum, nullus sum" (Soy insignificante, no soy nada) escribirá aún Burton, enunciando sin duda la espléndida ambivalecia del melancólico. En esta nada, el sujeto puede perderse, lacerarse, martirizarse, sufrir "el objeto" del que habla Freud: el "Remember" de Hamlet, la "herida y el cuchillo" de Baudelaire ...". Christine Buci-Glicksmann, "Le cogito mélancolique de la modernité", Le Magazine Littéraire 244 (París, julio-agosto, 1987) 39. 
Es por lo que podemos señalar que si lo cómico y la comedia han estado ligadas a la maldad y al ridículo, a algún tipo de inferioridad intelectual o moral, ${ }^{22}$ la actuación de Vicente Cochocho considerada desde la perspectiva melancólica de Las memorias, lejos de participar de los caracteres propios de lo cómico, se inscribe más bien en el rango de la santidad, de la más elevada espiritualidad humana.

Lo sublime y lo melancólico se alían en este personaje que emerge de esta otra belleza, transgresión que reivindica y recupera para nuestra literatura la estética y los lenguajes antes marginales e incluso "feos" de la inocencia, de lo humilde, de lo oral presentes en la infancia, en el medio rural y particularmente en el habla y comportamiento de los campesinos. Piedra Azul es pues el lugar de la infancia feliz. Una infancia terrenal y en cierto modo animal, en el sentido literal que otorga el contacto con las vacas ("Nube de agua" y "Nube de agüita"), los sapos, las mariposas y con los elementos, en general, de la naturaleza. Una infancia de juego, cuentos y trapiche, apenas intervenida por el poder civilizatorio de Evelyn y del padre, don Juan Manuel. Espacio de la ternura maternal que no puede sino recordarse con profunda nostalgia y melancolía. ${ }^{23}$ Piedra Azul es la metáfora del paraíso perdido, devastado, que el recuerdo en Las memorias reconstruye. Cuando las niñas tienen que abandonarlo por imposición del Padre es del Paraíso mismo de donde han sido expulsadas. La relación bíblica es evidente. Su tiempo es el de una Edad de Oro, mítica, sin historia, de una abundancia y prodigalidad extraordinarias. En contraste con este tiempo rural, de los orígenes, nos encontramos con el tiempo de la ciudad y de la escuela, "ese asilo de la melancolía y las letras", un tiempo reglamentado sometido a normas y convenciones. Desde la ciudad sabremos que Piedra Azul forma parte del interior de las niñas, a través del recuerdo y la nostalgia.

Lo que la escritura de Las memorias nos entrega es el tejido dialógico, polifónico, de ese pasado mítico, tocado por el oro de la distancia y la melancolía, bruscamente interrumpido por la transición a un tiempo y espacio de la regularidad y la monotonía. Hay en Primo Juancho, en Vicente Cochocho, en Evelyn, en los personajes, objetos y animales que habitan Piedra Azul, el encantamiento de un tiempo mágico que la escritura plural de Las memorias a través del contrapunto de voces y lenguajes, actualiza. Pero se trata de una actualización rasgada por la tristeza, por el sentimiento de pérdida, de

\footnotetext{
${ }^{22}$ Para Platón - dice Stern - "lo cómico fue una clase de maldad ... Los héroes clásicos de la comedia - antigua y moderna - se caracterizan todos por alguna inferioridad: intelectual, moral o social. Fue con toda justificación que Aristóteles definió la comedia como una imitación de hombres inferiores ...". Alfred Stern, Filosofia del llanto y de la risa. Traducción Julio Cortázar (Barcelona: Editorial Universitaria de Puerto Rico, 1975) 56-57.

${ }^{23}$ Según Jankélévitch "El objeto de la nostalgia no es tal o cual pasado, sino más bien el hecho del pasado, dicho de otro modo, la paseidad, la cual está con el pasado en la misma relación que la temporalidad con el tiempo ... Se puede decir ciertamente que la profundidad de la nostalgia es una profundidad biológica y que esta profundidad se llama: ruptura del cordón umbilical, separación del recién nacido del organismo materno, ligazón con la madre. Pero esta vinculación y esta separación misma no son para el hombre fuente sino porque son irreversibles y porque la pérdida de la 'beatitud' es definitiva, o recíprocamente: debido a que la ternura materna es irreversible es porque es el paraíso perdido". Vladimir Jankélévich, L'Irréversible et la nostalgie (París: Ediciones Flammarion, 1974) 357 y 368.
} 
naufragio, frente a ese tiempo — espacio edénico, celeste, "azul" - perfecto en su ritmo oral y circular.

En buena medida, lo que el amor y la melancolía nombran en Las memorias es una mudanza, el proceso de desaparición y tránsito de ese reino mágico que es una infancia presidida por la ternura materna a un estadio de más aguda conciencia y rigidez, presidido por la intervención del pasaje que es también un derrumbe, un desastre en la medida en que la escritura que lo poetiza está marcada por el dolor de una fractura. En efecto, la separación de las niñas de Piedra Azul, la ida a Caracas es profundamente desgarradora y sumerge la vida de las niñas en una cotidianidad herida, sin aliento. Reconocimiento de una ausencia, del vacío que deja la pérdida de esa plenitud original que es el juego y la relación lúdica con la madre, la escritura de Las memorias intenta colmar el vacío, apaciguar la herida, fundando de nuevo esta otra escena primitiva y lúdica que es la ficción y su diálogo seductor y ambiguo con el lector. Caracas aparece en el texto como la ruptura del cosmos, es la palabra del padre quien la impone, desarticulando así de algún modo la relación oral y maternal. Caracas impone la emergencia de una conciencia del pasado, impregnada de duelo y de melancolía. Vista a la distancia, la figura del padre cobra una aureola de herocidad y melancolía que lo eleva a la dignidad de un Bolívar. El padre es entonces el héroe inaccesible, suerte de fetiche místico, divinizado, magnánimo, que desde su poder y autoridad vigila, dirige, controla.

La madre, centro y origen de esa creación que es Piedra Azul, al narrar el mundo en las historias o relatos que cuenta a Blanca Nieves, lo vuelve a fundar en una temporalidad circular, que se cierra sobre sí misma. La memoria que enlaza maternidad e infancia es pues arcaica, mítica, se sueña y se reproduce sí misma, melancólicamente en cada nuevo relato. De todas las niñas, Blanca Nieves, la menor de las seis hermanas, parece tener una particular y natural inclinación hacia la melancolía. Es ella ciertamente la que ha sido poseída por el espíritu de la poesía a través de las narraciones que su madre suele contarle en el momento de hacerle los crespos y, en efecto, Blanca Nieves termina siendo cautivada y seducida por esta extraña pasión de contar cuentos, hasta el punto de que querrá transmitirla a las demás hermanas. Encontrará a este respecto la resistencia y la rebeldía de Violeta que se expresará a través de la ironía, la burla, el menosprecio. Vemos entonces cómo en torno a este hábito de contar cuentos se estimula la melancolía y el ensueño de Blanca Nieves, se incentiva también el amor y seducción de la madre, a la vez que se suscita la envidia y la rivalidad de Violeta. Una de las virtudes fundamentales de Las memorias es precisamente esta diferenciación discursiva, textual, de los personajes. La estructura dialógica y la vocación polifónica del texto se funda en esta diversidad de voces y lenguajes. Relacionado dialógicamente con este lenguaje de la melancolía y el amor maternal y humanitario de Blanca Nieves, la presencia de Aura, de Evelyn, de Violeta, del Primo Juancho, de Vicente Cochocho, significan la confirmación de una escritura dinámica y plural que se hace en conflicto e interrelación de lenguajes. Las memorias de Mamá Blanca es así esta red multiforme y plurivoca de lenguajes que establecen entre sí relaciones de oposiciones, de alianza o de solidaridad. De estas interrelaciones de voces, formas y lenguajes deriva la apertura significante del texto. Observamos entonces cómo las significaciones se complementan, se subrayan, se potencian o se oponen en contrapunto. A la melancolía y la expresión de lo amoroso y 
de la inteligencia humanística que se expresa en la madre, en Blanca Nieves o en Primo Juancho encontramos en significativa oposición el lenguaje y espíritu del progreso y de la técnica en el padre don Juan Manuel, en Evelyn, en Violeta.

Igualmente las significaciones de la melancolía y el amor estarán entretejidas, en relación de diálogo formal y semántico con las múltiples polivalencias de un humor a veces irónico, a veces alegre, en otras ocasiones más bien melancólico o crepuscular. A través de toda la novela y particularmente en personajes como Primo Juancho encontramos esta alianza de lo trágico y lo sublime, el humor y la melancolía, lenguajes disímiles y a la vez inextrincablemente relacionados entre sí y generadores de esa escritura tersa y deslumbrante de Las memorias de Mamá Blanca. 